\title{
Internalization of Character Values Through School Culture: Comparative Study of the Pre and Corona Pandemic Period
}

\author{
Esti Setiawati, Universitas PGRI Yogyakarta, Indonesia, esti@upy.ac.id, ORCID: 0000-0003-0365-0984 \\ Ika Ernawati, Universitas PGRI Yogyakarta, Indonesia, ika@upy.ac.id, ORCID: 0000-0002-1179-1085 \\ Marti Widya Sari, Universitas PGRI Yogyakarta, Indonesia, widya@upy.ac.id, ORCID: 0000-0003-4462-
} 5259

\begin{abstract}
This study aims to find out the character values developed by culture-based schools and to know the process of internalizing character values in the pre and corona pandemic period. This research uses a qualitative descriptive approach with comparative studies. Data collection techniques through interviews, observation, and documents. The results showed that: 1) character values developed by preschool and corona pandemic periods were in accordance with KDP guidelines, namely religious, nationalist, independent, mutual cooperation, and integrity; 2) internalization of character values in culture-based schools in the pre-pandemic corona is carried out through morning greetings, $5 \mathrm{~S}$ culture, folk songs, traditional clothes, batik, musical instruments, traditional games, and literacy culture; 3) supporting factors for internalizing character values are routine funding from the government, while the inhibiting factor is weak commitment and awareness of school members in the process of internalizing student character values.
\end{abstract}

Keywords: internalization, character values, school culture, comparative study

Received: 22.11.2020 Accepted: 05.12.2020 Published: 16.01.2021

\section{INTRODUCTION}

Building the character of a nation is not an easy matter and is not as easy as turning a hand, but it requires an ongoing process, quite a long time, a large cost, and the right strategy. Character education as a strategy designed to grow the right character and assess student morals (Kim, Choe, \& Kaufman, 2019). The implementation of character education is carried out by the teacher with strengthen verbal and nonverbal values (Utami, Amalia, Prayitno, Prihandini, \& Pradana, 2019). In implementing character education in schools, all stakeholders must be involved including the education component itself, namely the curriculum, learning process, assessment, cooperation, leadership, implementation of curricular activities, infrastructure, funding, and work ethics of all school residents (Harto, n.d.). This is impossible if there is no involvement of all elements of society, as education stakeholders (Ceyhan, Mugaloglu, \& Tillotson, 2019). However, even though the development of the nation's character has been touted by the government since 2010, it also has not been able to show optimal results in overcoming the existing moral degradation cases. Whereas character education has become a national movement to create schools as institutions that can grow young people who are ethical, responsible, and concerned with the moral development of the nation (Barry, Rice, \& Mcduffie-dipman, 2013). Therefore to build character values, one must also build organizational culture, especially spiritual character values, which are included in the vision and mission of the institution (Juharyanto, 2017) .

One of the big challenges in the era of globalization which increasingly surging, which is characterized by free competition and excellence, has an extraordinary impact on the world of education, especially the problem of character building for the younger generation (Wihyanti, Subiyantoro, \& Fadhilah, 2019) . This can be seen by the influence in the field of culture, with many western cultural values that are hedonistic, materialistic, pragmatic, and secularistic. Likewise with moral values, noble, spiritual, and transcendental values, increasingly neglected and increasingly eroded by the Indonesian people themselves. deep human process shaping character starts from the family, school and community (Hiroyuki, Juliawan, \& Sudarsana, 2018).

In addition, 21st century society requires individuals with high creativity to build a future with new leadership filled with change in this global era (Kim et al., 2019). Strategies that can be applied in the integration and implementation of this education are through an effective curriculum, optimal learning processes, good management, student activities, and the local culture of the school (Suriadi \& Mursidin, 2019). Other strategies through the process of transformation between students with each 
other, so that these values can be conveyed and internalized so that values and become an inseparable part of him (Suriadi \& Mursidin, 2019) .

Character education in schools is an effort in order to build student character (character building) towards a better direction than before. Character building through school culture is to instill values that are supported by school policies including education stakeholders which are implemented with full awareness as natural behavior, shaped by the environment (Suriadi \& Mursidin, 2019). In fact, students are said to have character if they have four criteria, namely knowing about the value of goodness, having the desire to do good, consistently doing good, and having a good influence on their environment (Sari \& Nurabadi, 2019).

Character education is value education which involves aspects of knowledge, feelings, and actions of students comprehensively, where value education will produce student character (Magda \& Patriana, 2016). Including providing value education to shape the character of students, must be formulated effectively because many negative factors affect students' deviant behavior (Eliasa, 2014). The character of the student is easily formed, when there is a lighter in the development of the character's values, because character concerns aspects of personality, which are related to students' beliefs, feelings, and actions as a whole (Rokhman, Hum, \& Syaifudin, 2014).

Lighters of character values, one of which is through the process of education and learning, because character education has a very large share in advancing the nation's civilization towards a nation that is knowledgeable, insightful, and characterless, and professional schools must develop a comprehensive curriculum to develop professional skills, while developing student character (Ed, Huber, \& Mafi, 2013) Besides that, character education is not something new in Indonesia, character education has been implemented in religious studies and citizenship education (Islami, 2016).

However, in its implementation, an appropriate strategy is needed, because there is a lot of character education currently running that tends towards cognitive not much towards behavioral implementation. Formation of character that has been running almost equated with certain activities, such as religious education, morals, and citizenship carried out incidentally (Handayani \& Rosliyah, 2020). Even though positive behavior should emerge when character education has been integrated and implemented well in schools, so that character is superior to intelligence. Character has a broad scope consisting of moral values, attitudes, and behavior in a comprehensive manner, which is reflected in good attitudes and actions in one's daily life (Rokhman et al., 2014). For that relevant character education implementation is integrating character education into all subjects that are the responsibility of the teacher in the school (Eliasa, 2014). The evidence shows that interpersonal character has a very important role in students' social adaptation, welfare, and life development (Liu, Xu, Xiao, Liu, \& Li, 2020). The learning process as the most strategic media that helps students build the desired character, especially through systematic and consistent learning models (Silanoi, 2012).

Character education integrated in the 2013 curriculum, aims to improve the quality and results of education, which leads to the formation of character and noble character of students in a whole, integrated and balanced in accordance with the Competency Standards of Graduates (SKL) in each education unit. Besides that character education is intended to improve the process and results of education which leads to the formation of an integral and balanced character according to graduates' competency standards at an educational level (Oktradiksa \& Magelang, 2017). Because in schools students and teachers can reflect back to pay attention to the quality and interaction of students when together in class and other school activities. The norms of a positive learning environment embrace and quickly develop the quality of valued characters (Gibbs, 1999). This requires that education as an agent of student character change, because through education allows students to function as agents of positive character change to develop good character (Berkowitz, 2011).

Through the implementation of the 2013 competency-based curriculum, with a thematic and contextual approach model, students are expected to be able to independently improve and use their knowledge, study and internalize and personalize the values of these characters and noble characters into their behavior and daily lives. This is in accordance with the general educational goals, namely to develop the potential of students to become human beings who obey God Almighty, noble character, healthy, knowledgeable, capable, creative, independent, democratic and responsible. In addition, education also has two main objectives, namely to guide the younger generation to be intelligent and to have virtuous behavior (Sari \& Nurabadi, 2019). Teachers who are prepared to teach must have good competence in their fields and have skills in character education to educate a qualified generation (Ülger, Yiğittir, \& Ercan, 2014).

Internalization of character values can be effective if supported by a good school climate, orderly, high culture, effective and supportive leadership, collaborative relationships, effective teaching methods, optimal student assessment and monitoring, and comprehensive parent and community involvement 
(Agostino, 2017). Some experts claim that character education is carried out well which has a synergy between the school and the family which is the basis of good initial character setting (Mei-ju, Chen-hsin, \& Pin-chen, 2014).

Starting from the previous presentation, reinforcement of character values is very interesting to be reviewed and explored, because through character education, the moral safety of the younger generation is at stake. Curricular approaches and learning for character building must co-exist and support one another (Was, Woltz, \& Drew, 2006). To strengthen character values so that students can easily be internalized, schools use forms of intervention, modeling, habituation, accompaniment, reinforcement, and involvement of various educational stakeholders, besides that the school internalizes character values to students through existing internal and external programs (Sudiami \& Subagyo, 2019) - Departing from this statement, the strengthening of character values can run well if accompanied by a positive school culture, which is able to accommodate and develop all the potential characteristics of students. For example, one of the basic orientations and principles of learning in pesantren is to benefit the community (Global Society) with noble character and besides maintaining good traditions (values) and making new innovations towards a better direction (Anam, Degeng, Murtadho, \& Kuswandi, 2019).

Important things that need to be done by schools is to optimize cultural values as a means of education to help students organize, conduct, and live a harmonious life in the family and community (Desyandri, 2018). Because the purpose of character education is to grow individuals who can understand moral values and apply them in the best course of action, and have the right purpose in life (Çubukçu, 2012). Character education should be carried out through activities outside of learning to foster discipline and social skills, as well as the characteristics of scientific disciplines (Wongwung, Tangdhanakanond, \& Wongwanich, 2014). Modern education is directed at improving the quality and effectiveness of an education system that is more adequate to improve the quality of the processes and expected outcomes (Zlatkovi, 2012).

Based on the results of temporary observations and existing documents, SMP Negeri 1 Jetis Bantul has a pretty good school life structure. This proved that the school dared to declare itself as a school based on culture, even though it was only at the beginner level. This is very relevant to previous findings that education as an agent of change that not only transfers knowledge, but also shapes students' attitudes, behaviors, and character (Rina, 2019). This courage is worthy of appreciation because the school launched 17 cultural-based school programs and activities, supported by a solid budget, teacher team and school board. However, it still needs to be investigated how to internalize character values in the corona pandemic. This research will focus on developing positive characters and character measurement through structured research to find out the characters that have been integrated and internalized in student behavior (Toner, Haslam, Robinson, \& Williams, 2012). The concept of critical thinking for future education is based on individuals by involving the community, for collaboration and communication, in the development of student character (Ed et al., 2013). Character education has broadly taught positive moral values, respect, citizenship, social skills, a sense of justice, and responsibility to students (Bailey, Tettegah, \& Bradley, 2006).

\section{METHOD}

This research method is a descriptive study through a qualitative approach. The research subjects were determined purposively according to the research objectives, namely one school principal, six teachers, six female students and four male students. Data collection methods through interviews, observation, and documentation. While the data analysis was carried out in a descriptive qualitative manner with a comparative study. The results of the study were analyzed through data collection methods, revisions, and analysis of existing research documents (Aragonés-González, Rosser-Limiñana, \& Gil-González, 2020).

\section{RESULTS AND DISCUSSION}

SMP Negeri 1 Jetis Bantul is a cultural-based school pilot as well as an environmentally friendly school, which is in line with the vision of the school "Achievement, Cultured, Love the Environment, Based on Imtaq and Science and Technology". The management and organization of education is carried out based on the national education system by upholding cultural values. The objectives of the culture-based school program are: 1) introducing students to cultural heritage; 2) love the cultural heritage of ancestors; 3 ) preserving cultural heritages; and 4) implementing ancestral heritage cultures in everyday life.

Based on the results of interviews, observations, and documentation during the pre and Corona pandemic period, the internalization process of character values is slightly hampered, especially during the corona pandemic, because the learning process is done online, students learn at home, so school 
control cannot be optimal . The description of the results of the internalization of character values shows differences in implementation during the pre and corona pandemic period.

Internalization of character values in Jetis 1 Junior High School in the corona pre pandemic can be done through 1) morning shake culture; 2) $5 \mathrm{~S}$ culture (smile, greetings, greetings, polite and polite); 3) there must be a Koran; 4) reading of the Bible; 5) sing the Indonesia Raya song; 6) the use of keroncong music and folk songs; 7) 3 language speeches; 8) batik painting at school; 9) use of traditional clothing; 10) the use of the "gendhing gamelan" instrument; 11) extra curricular karawitan; 12) use of Javanese language; 13) cultural corner; 14) traditional games; 15) batik skills; 16) culture of shame; and 17) literacy culture. One example of the activities to internalize character values is through musical activities that must be followed by all students, which can be seen in Figure 1 .

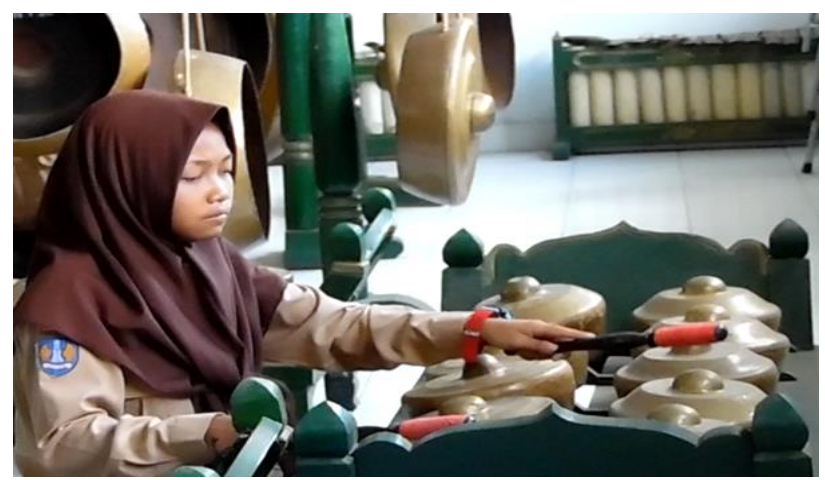

Figure 1. Students Practice Karawitan

Whereas the internalization of character values during the corona pandemic was carried out through a tri center approach to education, which involved school education, family education, and community education in an optimal and balanced manner.

To monitor the entire implementation of the learning process during the corona pandemic, the school made a strategy so that the entire process could run well and in accordance with the guidelines given by the government. These strategies include: a) schools develop distance learning instruments (PJJ); b) schools conduct data collection on distance learning (PJJ); c) schools conduct reflections and evaluations through limited teacher briefings; and d) schools follow up with improvements in the implementation of distance learning (PJJ).

Internalization of character values that have been carried out in SMP Negeri 1 Jetis Bantul in the pre and corona pandemic period needs to be evaluated periodically, because in pre-corona implementation has not been maximized, plus the corona pandemic period, schools find it difficult to assess student character development directly because students study online. Character evaluation is certainly different from other evaluations, because character evaluation is an evaluation of behavior as an output from internalizing character values (Critcher, Helzer, \& Tannenbaum, 2020). Two important things that need to be evaluated during online learning are the effectiveness of the activity student character development and the impact of these activities, including other program interventions (Berkowitz, 2011).

The strategy that needs to be carried out by schools is to develop a standard implementation and evaluation format about internalizing character values during online learning. In addition, schools must collaborate synergistically with families and communities, to be actively involved in overseeing the development of student character. Important things that need to be understood that the inculcation of character values can be done through formal education, informal and informal. This means that character education is not only a responsibility in the world of education, but also a shared responsibility between the government, community, family, and school (Utami et al., 2019).

The most crucial thing is the role of the teacher, because the teacher has a very large role in instilling values through learning that must be done with the right strategies, methods, and teaching techniques (Şahinkayasi \& Kelleci, 2013). Likewise, education in the community, has given opportunities to students to gain experience and provide opportunities to actively participate in developing positive attitudes (Feszterova \& Jomova, 2015). Beside in addition, educational organizations urge teachers to develop curricula that not only develop academic fields but must also develop student character (Ed et al., 2013). The next step, character education must be linked to formal education programs and other programs that focus on developing dimensions of positive behavior to face the challenges of life now and in the future (Matsuba, Murzyn, \& Hart, 2011). 
The role of education and government must be balanced which must work together synergistically in helping to play a very central family function in fostering the character of students (Kamalia et al., 2019). An effective student character development model is emphasizing the need for praise, encouragement, and appreciation for students, as well as modeling the role of the teacher that can be used as a role model (Arthur, 2011). Nevertheless, the current despite policy of the pandemic that is taking place in many countries has been promoting learning through digital devices online for students, but must be equipped with manuals so that students get optimal benefits from learning (Hartikainen, Iivari, \& Kinnula, 2019).

\section{CONCLUSIONS}

Strengthening the character values in SMP Negeri 1 Jetis Bantul pre pandemic corona is carried out through programs and activities including: 1) morning shake culture; 2) $5 \mathrm{~S}$ culture (smile, greetings, greetings, polite and polite); 3) there must be a Koran; 4) reading of the Bible; 5) sing the Indonesia Raya song; 6) the use of keroncong music and folk songs; 7) 3 language speeches; 8) batik painting at school; 9) use of traditional clothing; 10) the use of the "gendhing gamelan" instrument; 11) extra curricular karawitan; 12) use of Javanese language; 13) cultural corner; 14) traditional games; 15) batik skills; 16) culture of shame; and 17) literacy culture.

Whereas the reinforcement of character values during the corona pandemic was carried out through the tri education center approach, which involved school education, family education, and community education.

\section{ACKNOWLEDGEMENT}

This research and publication is supported by The International Reputable Journal Acceleration (AJIB) UPY and The Institute of Research and Community Services (LPPM) Universitas PGRI Yogyakarta.

\section{REFERENCES}

Agostino, T. J. D. (2017). International Journal of Educational Development Precarious values in publicly funded religious schools: The e ff ects of government-aid on the institutional character of Ugandan Catholic schools. International Journal of Educational Development, 57(March), 30-43.

Anam, S., Degeng, I. N. S., Murtadho, N., \& Kuswandi, D. (2019). The moral education and internalization of humanitarian values in pesantren. Journal for the Education of Gifted Young Scientists, 7(4), 815-834.

Aragonés-González, M., Rosser-Limiñana, A., \& Gil-González, D. (2020). Coeducation and gender equality in education systems: A scoping review. Children and Youth Services Review, 111, 104837.

Arthur, J. (2011). Personal character and tomorrow's citizens: Student expectations of their teachers. International Journal of Educational Research, 50(3), 184-189.

Bailey, B. P., Tettegah, S. Y., \& Bradley, T. J. (2006). Clover: Connecting technology and character education using personally-constructed animated vignettes. Interacting with Computers, 18(4), 793-819.

Barry, A. L., Rice, S., \& Mcduffie-dipman, M. (2013). The journal of social studies research books with potential for character education and a literacy-rich social studies classroom: a research study. The Journal of Social Studies Research, 37(1), 47-61.

Berkowitz, M. W. (2011). What works in values education. International Journal of Educational Research, 50(3), 153-158.

Ceyhan, G. D., Mugaloglu, E. Z., \& Tillotson, J. W. (2019). Teaching socio-scientific issues through evidencebased thinking practices: Appropriateness, benefits, and challenges of using an instructional scaffold. Elementary Education Online, 18(4), 1405-1417.

Critcher, C. R., Helzer, E. G., \& Tannenbaum, D. (2020). Moral character evaluation: Testing another's moral-cognitive machinery. Journal of Experimental Social Psychology, 87(September 2019), 103906.

Çubukçu, Z. (2012). The effect of hidden curriculum on character education process of primary school students, 12(2), 1526-1534.

Desyandri. (2018). Internalization of local wisdom values through music art as stimulation of strengthening character education in early childhood education; a hermeneutic Analysis and Ethnography Studies, 169(Icece 2017), 13-16.

Ed, J. A., Huber, M. M., \& Mafi, S. L. (2013). Education par excellence: developing personal competencies and character through philanthropy-based education. Journal of Accounting Education, 31(3), 310332 . 
Eliasa, E. I. (2014). Increasing values of teamwork and responsibility of the students through games: integrating education character in lectures. Procedia - Social and Behavioral Sciences, 123, 196-203.

Feszterova, M., \& Jomova, K. (2015). Character of Innovations in Environmental Education. Procedia Social and Behavioral Sciences, 197(February), 1697-1702.

Gibbs, J. (1999). Internalizing character education values by living and learning within a caring school community, 1-6.

Handayani, S., \& Rosliyah, Y. (2020). Internalization of character values through project- based learning, specifically children's Song translation, 397(Icliqe 2019), 1278-1286.

Hartikainen, H., Iivari, N., \& Kinnula, M. (2019). Children's design recommendations for online safety educationo. International Journal of Child-Computer Interaction, 100146.

Harto, K. (n.d.). Developing character internalization model in islamic education through value clarification technique, (0711).

Hiroyuki, A., Juliawan, J., \& Sudarsana, I. K. (2018). Internalization values of character education towards the teruna-daha in the medi-median tradition. Vidyottama Sanatana: International Journal of Hindu Science and Religious Studies, 2(2), 232.

Islami, M. (2016). Character values and their internalization in teaching and learning english at madrasah. Dinamika Ilmu, 16(2), 279.

Juharyanto. (2017). the international of spiritual based characters value in building the culture of education organizations, $1(1)$.

Kamalia, S., Yogyakarta, U. N., Indartono, S., Yogyakarta, U. N., Islamiah, R., \& Indonesia, U. P. (2019). The Role of families on internalization of the tolerance values for millennial generation to decrease the potential of intolerant conflict and radicalism behavior within the multi religion society, 323 (ICoSSCE 2018), 316-325.

Kim, S., Choe, I., \& Kaufman, J. C. (2019). The development and evaluation of the effect of creative problem- solving program on young children's creativity and character. Thinking Skills and Creativity, 33 (August 2018), 100590.

Liu, L., Xu, L., Xiao, X., Liu, L., \& Li, Y. (2020). Positive in fl uence of peers' interpersonal character on children's interpersonal character: The moderating role of children ' $s$ and peers ' social status. Journal of Adolescence, 79(January), 157-172.

Magda, M., \& Patriana, R. (2016). The significance of environmental contents in character education for quality of life. Procedia - Social and Behavioral Sciences, 222, 244-252.

Matsuba, M. K., Murzyn, T., \& Hart, D. (2011). A model of moral identity. Applications for education. Advances in Child Development and Behavior (1st ed., Vol. 40). Elsevier Inc.

Mei-ju, C., Chen-hsin, Y., \& Pin-chen, H. (2014). The beauty of character education on preschool children' s parent-child relationship. Procedia - Social and Behavioral Sciences, 143, 527-533.

Oktradiksa, A., \& Magelang, U. M. (2017). Reinterpretation of national education standard in planning of quality improvement for madrasah ibtidaiyah flagship.

Rina, L. (2019). Student leadership in school: internalization of entrepreneurial competence and character. Jurnal Manajemen Dan Kewirausahaan, 21(1), 1-8.

Rokhman, F., Hum, M., \& Syaifudin, A. (2014). Character education for golden generation 2045 (national character building for indonesian golden years). Procedia - Social and Behavioral Sciences, 141, 1161-1165.

Şahinkayasi, Y., \& Kelleci, Ö. (2013). Elementary School Teachers' Views on Values Education. Procedia Social and Behavioral Sciences, 93, 116-120.

Sari, Y. L., \& Nurabadi, A. (2019). Internalization of character values in learning at institution of english course, 382(Icet), 630-635.

Silanoi, L. (2012). The Development of Teaching Pattern for Promoting the Building up of Character Education Based on Sufficiency Economy Philosophy in Thailand. Procedia - Social and Behavioral Sciences, 69(Iceepsy), 1812-1816.

Sudiami, D., \& Subagyo, M. \&. (2019). Internalization of social value based on character education strengthening through scouting extracurricular activities in public junior high school 1 Batang, 8(274), 68-76.

Suriadi, S., \& Mursidin, M. (2019). Internalization of Cultural Values in Schools Early Steps in Building Nation Characters.

Toner, E., Haslam, N., Robinson, J., \& Williams, P. (2012). Character strengths and wellbeing in adolescence: structure and correlates of the values in action Inventory of strengths for children. Personality and Individual Differences, 52(5), 637-642.

Ülger, M., Yiğittir, S., \& Ercan, O. (2014). Secondary School Teachers' Beliefs on Character Education Competency. Procedia - Social and Behavioral Sciences, 131(4310), 442-449. 
Utami, R., Amalia, N., Prayitno, H., Prihandini, T., \& Pradana, F. (2019). Internalization of character value of social care for madrasah students ibtidaiyah muhammadiyah in education disruption era, (January).

Was, C. A., Woltz, D. J., \& Drew, C. (2006). Evaluating character education programs and missing the target: A critique of existing research, 1, 148-156.

Wihyanti, R., Subiyantoro, S., \& Fadhilah, S. S. (2019). Exploring collaboration pattern of guidance and counseling' implementers in the primary school. Elementary Education Online, 18(2), 482-495.

Wongwung, A., Tangdhanakanond, K., \& Wongwanich, S. (2014). Change Model of Attributes of Students in Terms of Discipline, Sufficiency Living and Public Mind from Character Education Activities. Procedia - Social and Behavioral Sciences, 116, 3996-3999.

Zlatkovi, B. (2012). teachers' education for a more flexible approach to character analysis in literary creations, 45, 486-492. 